that the proposed building was necessary and would not adversely affect the character of the church building. The faculty was granted. [WA]

doi:10.1017/So956618X10000335

\title{
Ladele v Islington Borough Council and Liberty
}

Court of Appeal: Lord Neuberger of Abbotsbury MR, Dyson and Smith LJJ; December 2009

Registrar - discrimination - civil partnerships

The appellant, a registrar of marriages, sought to reverse the decision of the Employment Appeals Tribunal and reinstate the decision of the Employment Tribunal ${ }^{1}$ that her employer was guilty of discrimination (both direct and indirect) under the Employment Equality (Religion or Belief) Regulations 2003, SI 2003/1660, by compelling her to register civil partnerships, to which she has an objection based on her religious beliefs. The local authority sought to show that it had no option but to compel the appellant to register such partnerships. In dismissing the appeal the court upheld the judgment of the EAT and judged that the actions of the council were proportionate to the legitimate aim of implementing their 'Dignity for All' policy, which was aimed not only at countering discrimination in the wider community, but also within the departments of the council. Furthermore, the appellant could not claim breach of her rights under Article 9 of the European Convention on Human Rights, as the legitimate aim of the council could not be overridden by her desire that her religious views be respected. Liberty, who had intervened, argued, and the court accepted, that a registrar who is prepared to perform marriages discriminates if he refuses to perform civil partnerships (Equality Act (Sexual Orientation) Regulations 2007 , SI 2007/1263); that the regulations themselves state that, for their purposes, marriage and civil partnership are not materially different; that a civil partnership is a public service and the council and registrar public bodies; and that the council could be liable for the registrar's refusal, especially as she had been designated as a civil partnership registrar. The court noted that if a registrar had not been designated as a civil partnership registrar then questions under the 2007 regulations would not arise. However, the fact that she was so registered did not amount to direct or indirect discrimination against her by the council. [WA] 